\title{
TEACHING WRITING THROUGH PROCESS-GENRE METHOD
}

\author{
Santi Ariyanti \\ Pendidikan Bahasa Inggris STKIP Nurul Huda Sukaraja \\ santiariyanti14031998@gmail.com
}

\begin{abstract}
The main problem of this study was "Is it effective to teach writing through the process-genre method to the tenthgrade students of Islamic Senior High School NU Yosowinangun?". The objective of this study is to find out whether the process-genre method was effective to teach writing to the tenth-grade students of Islamic Senior High School NU Yosowinangun, writing ability of descriptive text. This research used a quantitative research method using the pre-experimental method. The population of the study was all the tenth-grade students of Islamic Senior High School NU Yosowinangun in the academic 2019/2020, with 106 students. The sample was 20 students taken by using one stage cluster random sampling. The data were analyzed through the matched t-test formula to find out the effectiveness of teaching writing through the process-genre method. The technique for collecting data used a written test twice in the pre-testand post-test. Based on the result of the data analys is, it was found that the highest score in the pre-test was 69 and the lowest score was 41 , and the average score was 52.8 . While in the post-test, the highest score was 85 and the lowest score was 70 , where the average score was 79 , it was found that the value of $t$-obt was 18.7, where the value of t-tab was 1.725 , at significance level 0.05 or $95 \%$ with a degree of freedom. . It can be concluded that the null hypothesis $(\mathrm{Ho})$ was rejected and the alternative hypothesis $(\mathrm{Ha})$ was accepted. It indicated that teaching writing through the process-genre method to the tenth-grade students of Islamic Senior High School NU Yosowinangun was effective.
\end{abstract}

Keywords: writing, process-genre method, descriptive paragraph

\section{INTRODUCTION}

English is an important language, especially when people go abroad. The importance of the role of English in the International at the moment cannot be denied, English as a global language of communication will increasingly be used in various aspects of international activities. According to Cook (2003: 13), four hundred million or so first-language speakers, and over a billion people who live in a country where it is an official language, English now taught as the main foreign language in virtually every country and used for business, education, and access to information by a substantial proportion of the world's population. See the role of English now in various aspects, the Indonesian government included English into the school curriculum taught to students.

Writing is one of the skills in English learning. Students are not only expected to speak English fluently, but also able to use other language skills (listening, reading, and writing). Among the four skills, writing is a complex process. Furthermore, writing differs from other skills. It is unique. It means that the students should learn many aspects of writing such as kinds of words, vocabularies, correct phrases, patterns of sentences, paragraphs, and ideas. Moreover, they should discover more and more details and think precisely of the facts, ideas, and everything related to the subject. Thus, they must focus on accurate language use, and because they think as they write, it will provoke language development as they resolve problems that the writer puts into their mind (Harmer, 2007:31).

According to Badger and White (2000:157), the process method has been criticized because it views the process as the same for all writers, regardless of what is being written and who is doing the writing, and because it gives insufficient importance to the purpose and social context of the piece of writing. Nevertheless, the process method is widely accepted and utilized because it allows students to understand the steps involved in writing, and it recognizes that what learners bring to the writing classroom contributes to the development of the writing skill. Yan (2005:5) states that the process genre approach help teacher in uniting all these aspects, motivate the students in writing, and also preparing the students in writing outside the classroom. Moreover, Babalola and Litinin (2012:4) said 
that the process genre approach is a combination of two approaches which can help in developing students' writing skills. Badger and White (2000: 157-158) state that the Process Genre Approach regards writing as a process that includes knowledge of the language, knowledge of the context and purpose (as in genre approach), and skills in using language (as in-process approach).

Genre is quite easily used to refer to a distinctive category of the discourse of any type, spoken or written, with or without literary aspirations (Swales, 1998: 33). Hyland (2004: 4) also writes that genre is a term for grouping a text, representing how writers typically use language to respond to the recurring situation. This means that genre is a type of written and oral text used to tell something in such a situation.

As its name, focuses on the students' writing as the product of writing class. However, in this approach, the students write their composition in the last stage, free writing. From the beginning of writing class, the teacher plays such an important role to make students familiar with a certain genre by giving the model text and by explaining the related grammar and vocabulary. Based on the model text, the students then learn the grammar, expression, or vocabulary used in the genre. After they have mastered the knowledge of the language, they start writing but are guided by the teacher. This process does not challenge students because they just follow what is instructed by the teacher and try to understand what is explained by the teacher. It is very important for them to thoroughly understand the teacher's explanation about the related genre, grammar, and vocabulary because, at the end of writing class, they should write a piece of writing which is similar to the model given in the beginning. This is the essence of teaching writing using the Product Approach: focusing on the students' final product, a piece of writing. This is in line with the nature of the Product Approach stated by Raimes (cited in Tangpermpoon, 2008: 2) that it focuses on grammatical and syntactic forms. Consequently, the writing process is put off until the very end of the writing process (Tangpermpoon, 2008: 5).

\section{METHODOLOGY}

This study used the pre-experimental method. In this pre-experimental method, applied the onegroup pretest-posttest design. There was only one group of students involved. In the one-group pretest-posttest design, a single group is measured or observed not only after being exposed to a treatment of some sort but also before (Fraenkel \& Wallen, at all, 2011:269).

The research variable is an attribute of a person or an object which varies from time to time. There were two kinds of variables in this study. They were an independent variable and a dependent variable. The dependent variable is the major variable to be investigated. In this study, the independent variable is the treatment of teaching writing through the process-genre method. On the other hand, the dependent variable of this study is the students' scores on the tests of writing a paragraph.

The participants of this research were one class of the first semester students of Islamic senior high school NU Yosowinangun in the academic year of 2019/2020 with 20 students. The classes were randomly selected and it resulted that X.1 was the experimental group. The instruments used for the research were lesson plans, questionnaires on self-esteem, and writing tests. The students in the experimental class were subjected to treatment with the Process-Genre Approach.

\section{RESULT AND DISCUSSION}

After analyzing the data gathered from the test, there were three findings in this study: (1) the students' mean and reliability score in the pre-test, (2) the students' mean and reliability score in the post-test, and (3) the result of t-obtained. The students' mean score in the pre-test was 52.8 and the score of reliability in the pre-test was 0.95 . The students' mean score in the post-test was 79 and the score of reliability was 0.97 . The result of the calculation of the matched t-test was 18.7 as the value of $\mathrm{t}$-obtained. The value of $\mathrm{t}$-obtained was higher than the $\mathrm{t}$-table (1.725). Then the null hypothesis $(\mathrm{Ho})$ was rejected and the alternative hypothesis $(\mathrm{Ha})$ was accepted. 
The writer gave students a pre-test experimental group before conducted the experiment, and then calculated the students' score. After the writer gave 6 times for treatment to the students in the teaching writing process - genre method, the writer gave the students a post-test which was intended to know how far the students' progress in their writing. In the pre-test and post-test the sample of the students were 20 students. The data on the frequency of the students' scores could be seen in the chart below.

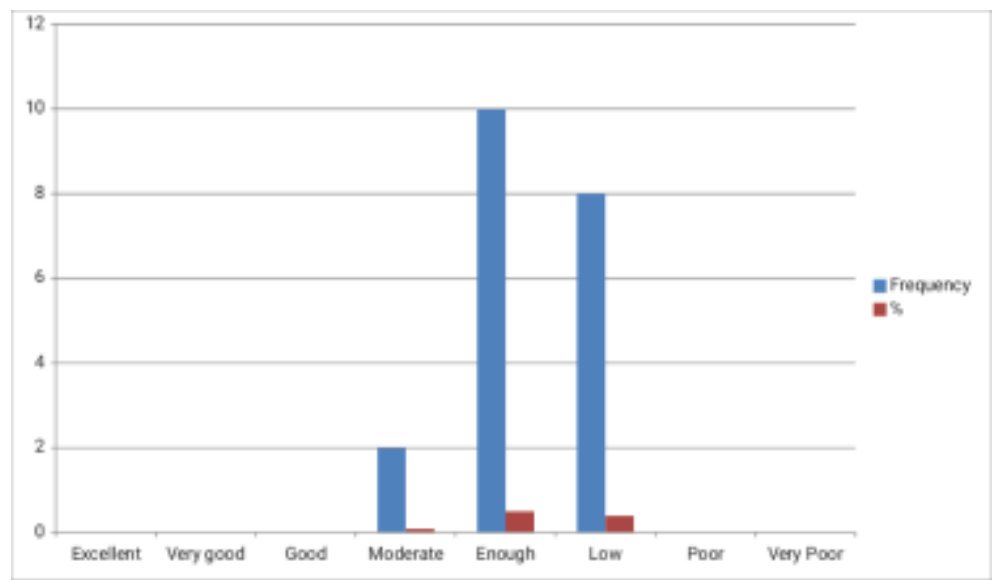

\section{Chart 1. Pre-Test Score in Experimental Group}

It was found that there were 2 students $(10 \%)$ who got a moderate score and there were 10 students $(50 \%)$ who got enough score. Meanwhile, for the low score, there were 8 students $(40 \%)$. While excellent, very good, good, poor, and very poor score no student there were

After taking the pre-test, the students were introduced to how to make a good descriptive paragraph through the process-genre method. After doing that, the students had the post-test. The data obtained were calculated by rater I and rater II for the vocabulary, structure, organization, content, and mechanics. They were then ranked. After being analyzed, it was found that the highest score in the post-test was 85 (achieved by 1 student), the lowest score was 70 (achieved by 1 student)

It was found that were 11 students $(55 \%)$ who got a very good score and there were 8 students (40\%) who got a good score. Meanwhile, for the moderate score, there was 1 student $(5 \%)$. While excellent, enough, low, poor, and very poor score no student there was.

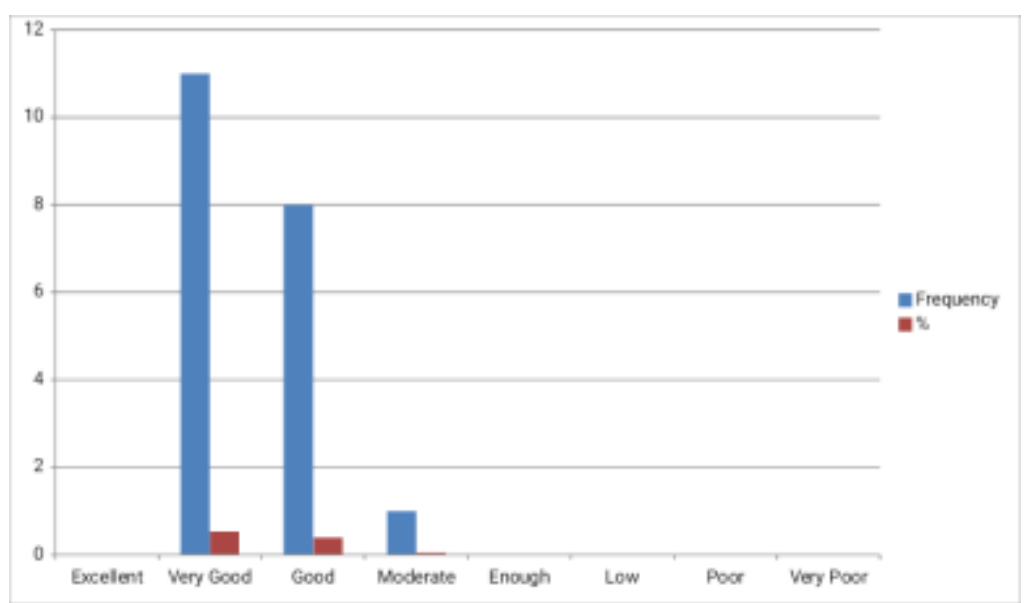

\section{Chart 2. Post-Test Score in Experimental Group}

From the students' mean score in the post-test and pre-test of the test, the matched t-test calculation showed that the value of $t$-obtained was 18.7. The value of the $t$-table was 1.725 . It could be concluded that the value of t-obtained (18.7) was higher than the value of t-table. 
Then the null hypothesis $(\mathrm{Ho})$ was rejected and the alternative hypothesis $(\mathrm{Ha})$ was accepted. It means that it was effective through the process-genre method in teaching writing.

\section{CONCLUSION}

Based on the findings and interpretations in the previous chapter, it can be concluded that teaching writing through the process-genre method to the tenth-grade students of Islamic Senior High School NU Yosowinangun was effective in improving students' ability in writing. It was evidenced in the value of the t-obtained was higher than the value of the $t$-table (18.7> 1.725). So, the null hypothesis ( $\mathrm{Ho}$ ) was rejected and the alternative hypothesis ( $\mathrm{Ha}$ ) was accepted. This happened because through the process-genre method the students could think creatively in writing so they were able to develop a descriptive well. Besides, it proved that students' mean score in the post-test was higher than in the pre-test $(84.5>58.3)$.

\section{REFERENCIES}

Babalola \& Litinin, H. A. (2012). Effects of Process-Genre Based Approach on the Written English Performance of Computer Science Students in a Nigerian Polytechnic. Journal of Education and Practice. Vol 3, No 6, 2012

Badger, R. \& White, G. (2000). A Process-Genre Approach to Teaching Writing: Article in ELT Journal.RetrievedMarch2nd,2016,fromhttps://www.researchgate.net/publication/31211 $657 \mathrm{~A}$ process genre approach to teaching writing

Cook, (2003). Language Acquisition. An examination of Chinese

Fraenkel, J. R. \& Wallen, N. E. (2005). How to Design and Evaluate Research in Education (6 ${ }^{\text {th }}$ Ed.).New York: McGraw-Hill Compaines, Inc.

Fraenkel, J. R., Wallen, N. E., \& Hyun, H. H. (2011). How to Design and Evaluate Research in Education. New York: McGraw, Hill, Inc.

Harmer, J. (2007). How to Teach Writing. England: Longman Group.

Hyland, K. (2003). Second Language Writing. New York: Cambridge University Press.

Swales, J. (1998). English in academic and research settings. Cambridge, U.K.: Cambridge University Press.

Tangpermpoon, T. (2008). Integrated Approaches to Improve Students Writing Skills for English Major Students. ABAC Journal, 28(2): 1-9.

Yan, G. (2005). A Process Genre Model for Teaching Writing. English Teaching forum 43, 3. p 18 